\title{
Effects of Mold Oil Containing $\gamma$-Linolenic Acid on the Blood Cholesterol and Eicosanoid Levels in Rats
}

\author{
Michihiro Sugano, Takahiro Ishida, Katsuko Yoshida, \\ Kazunari TANaKa, ${ }^{*}$ Motohiro NiWA, ${ }^{* *}$ Masahiro Arima** \\ and Akihito MorITA** \\ Laboratory of Nutrition Chemistry, Kyushu University School of Agriculture \\ 46-09, Fukuoka 812, Japan \\ * Laboratory of Nutrition, Nagasaki Women's College, \\ Nagasaki 850, Japan \\ ** Brewing Science Laboratory, Kirin Brewery Co., Ltd., \\ Takasaki, 370-12, Japan
}

Received March 25, 1986

\begin{abstract}
The oil produced by the mold Mortierella ramanniana var. angulispora IFO 8187, containing approximately $6 \%$ of $\gamma$-linolenic acid (GLA) and $10 \%$ linoleic acid (LA), was examined for its effects on blood cholesterol and eicosanoid levels in rats. When rats were fed cholesterol-enriched diets containing $10 \%$ fats, the hypocholesterolemic activity of the mold oil was comparable with that of safflower oil containing $75 \%$ LA and was significantly greater than in palm olein containing $16 \%$ LA. That the hypocholesterolemic effect could be ascribed exclusively to GLA was confirmed by comparing the effects of ethyl-GLA prepared from the mold oil and ethyl-LA. In rats fed the mold oil the aortic production of $\mathrm{PGI}_{2}$ tended to be higher, whereas the level of plasma $\mathrm{TXB}_{2}$ was similar to or lower than those in rats fed safflower oil. The specific activity of $\Delta^{6}$-desaturase in liver microsomes was significantly higher and the ratio of arachidonate/linoleate in liver phosphatidylcholine was much higher in the mold oil than in safflower oil. These results are indicative of the specific function of the Mortierella oil in the regulation of eicosanoid production as well as cholesterol metabolism.
\end{abstract}

Dietary treatment of hypercholesterolemia by polyunsaturated fatty acids, almost exclusively as linoleic acid (LA), has long been accepted as one of the most effective and practical means to lower the plasma cholesterol level. ${ }^{1,2)}$ However, a wealth of observations that relatively large amounts of LA are required to accomplish this purpose renders the use of LA restrictive. Studies on the effect of the dietary fat types on the immune response or the promotion of some types of cancer strongly indicate possible untoward effects of LA on these parameters. ${ }^{3,4)}$ Thus, it seems reasonable to find fatty acid(s) alternative to LA.

The possible candidates for this purpose are the metabolites of LA such as $\gamma$-linolenic acid (GLA) and arachidonic acid (AA).
These metabolites have much greater hypocholesterolemic activity than the parent molecule. ${ }^{510)}$ One problem encountered in the use of LA metabolites is that the natural sources are quite limited. For GLA, evening primrose oil is practically the sole source, but the content of GLA seldom exceeds $10 \%$ of total fatty acids ${ }^{11)}$ in addition to the quite low production.

Recently, Suzuki et al. ${ }^{12)}$ have found that several genera of molds can produce lipids containing GLA. The level of GLA varies depending on the cultivation conditions, and it is now possible to produce triglycerides containing more than $10 \%$ GLA. In contrast to evening primrose oil, the mold oil contains less LA and more oleic and palmitic acids. ${ }^{12)}$ Thus, this mold oil could be a novel source 
of the hypocholesterolemic agents having less, if any, possible untoward propensities. Our studies were undertaken to confirm the cholesterol-lowering efficacy of the mold oil containing GLA. The hypocholesterolemic effects of ethyl-GLA prepared from the mold oil were also compared with those of ethyl-LA.

\section{MATERIALS AND METHODS}

Materials. Mortierella ramanniana var. angulispora IFO 8187 was cultivated in liquid medium under aeration at $30^{\circ} \mathrm{C}$ for $72 \mathrm{hr}$. The medium contained per 1,000 $\mathrm{ml}$ deionized water, $200 \mathrm{~g}$ of glucose, $9.0 \mathrm{~g}$ of $\mathrm{KH}_{2} \mathrm{PO}_{4}$, $5.0 \mathrm{~g}$ of $\left(\mathrm{NH}_{2}\right)_{2} \mathrm{CO}, 2.25 \mathrm{~g}$ of $\left(\mathrm{NH}_{2}\right)_{4} \mathrm{SO}_{4}, 1.0 \mathrm{~g}$ of $\mathrm{MgSO}_{4}$. $7 \mathrm{H}_{2} \mathrm{O}, 0.3 \mathrm{~g}$ of $\mathrm{NaCl}, 0.6 \mathrm{~g}$ of malt extract, $0.6 \mathrm{~g}$ of yeast extract, $0.3 \mathrm{~g}$ of peptone, $30 \mathrm{mg}$ of $\mathrm{FeSO}_{4} \cdot 7 \mathrm{H}_{2} \mathrm{O}, 3.6 \mathrm{mg}$ of $\mathrm{CaCl}_{2} \cdot 2 \mathrm{H}_{2} \mathrm{O}, 0.6 \mathrm{mg}$ of $\mathrm{CuSO}_{4} \cdot 5 \mathrm{H}_{2} \mathrm{O}, 3.0 \mathrm{mg}$ of $\mathrm{ZnSO}_{4} \cdot 7 \mathrm{H}_{2} \mathrm{O}$, and $3.0 \mathrm{mg} \mathrm{MnCl}_{2} \cdot 4 \mathrm{H}_{2} \mathrm{O}, \mathrm{pH}$ 4.6. The cells were harvested by filtering them through a filter press and dehydrating with ethanol in a ball mill (in the initial trial the cells were autoclaved at $120^{\circ} \mathrm{C}$ for $10 \mathrm{~min}$ before dehydration). The dehydrated cells were then extracted with hexane and the solvent removed in a rotary evaporator. The resulting oil was composed of $86 \%$ triglycerides, $12 \%$ diglycerides, and other minor lipid components. In Exp. 1 this crude oil was used. The crude oil was refined by the procedure commonly used for the commercial edible oils and a refined oil with more than $98 \%$ triglycerides was obtained. This refined oil was used in Exp. 2. Mold oil was also transesterified in ethanol containing sulfuric acid as a catalyst and the re- sulting ethyl ester was treated with urea. ${ }^{13)}$ After repeatedly removing the urea adducts, ethyl-GLA was purified by silicic acid column chromatography. The purified product was used in Exp. 3-1. Ethyl-LA was a gift from Nihon Oil Co., Tokyo and was used in Exp. 3-2. These ethyl esters gave single spot each on thin-layer chromatography. Palm oil and palm olein were provided by the Fuji Oil Co., Osaka. Safflower oil was offered by Nissin Oil Co., Tokyo. The fatty acid compositions of these oils are presented in Table I together with plant sterol contents.

Animals and diets. Animals used in these studies were specific-pathogen-free male Sprague-Dawley rats purchased from the Seiwa Experimental Animals, Ltd., Fukuoka. They were housed individually in a temperature and light controlled room $\left(20 \sim 23^{\circ} \mathrm{C}\right.$, lighting on 0800 to $2000 \mathrm{hr}$ ) and acclimated for a few days after arrival. In all trials shown below, rats were allowed free access to experimental diets and water, and body weight and food intake were recorded every other day.

Exp. 1. Rats weighing an average of $95 \mathrm{~g}$ were fed on the experimental diet (Diet 1 in Table II) for 24 days and after overnight fasting (1700 to $0900 \mathrm{hr}$ ) blood was withdrawn under ethyl ether anesthesia from the abdominal aorta in a syringe containing $3.8 \% \mathrm{Na}_{3}$-citrate $(1 \mathrm{ml}$ for $9 \mathrm{ml}$ blood) and indomethacin (final concentration $10^{-4}$ $\mathrm{mol} / \mathrm{l}$ ) and plasma was collected. Dietary fat sources were the crude mold oil and safflower oil.

Exp. 2. Rats weighing an average of $107 \mathrm{~g}$ were initially fed on the experimental diet (Diet 2 in Table II) for 3 weeks and then on the diets free of cholesterol and $\mathrm{Na}$ cholate for additional 3 weeks. Dietary fat sources were the refined mold oil, safflower oil, and palm olein. A small

Table I. Fatty Acid Compositions of Dietary Fats

\begin{tabular}{|c|c|c|c|c|c|c|c|c|}
\hline \multirow{2}{*}{ Dietary fats } & \multicolumn{7}{|c|}{ Fatty acids (weight $\%$ ) } & \multirow{2}{*}{$\begin{array}{c}\text { Plant } \\
\text { sterols }^{a}\end{array}$} \\
\hline & $16: 0$ & $16: 1$ & $18: 0$ & $18: 1$ & $18: 2$ & $18: 3(\mathrm{n} 6)$ & $18: 3(\mathrm{n} 3)$ & \\
\hline \multicolumn{9}{|l|}{ Exp. 1} \\
\hline Safflower oil ${ }^{b}$ & 6.8 & - & 1.5 & 13.4 & 75.1 & - & 2.0 & 183 \\
\hline Mold oil & 28.4 & 1.1 & 7.1 & 45.9 & 9.8 & 6.5 & - & 473 \\
\hline \multicolumn{9}{|l|}{ Exp. 2} \\
\hline Safflower oil ${ }^{b}$ & 7.1 & - & 2.0 & 12.3 & 77.4 & - & 1.1 & 330 \\
\hline Palm olein ${ }^{d}$ & 31.2 & - & 1.9 & 48.7 & 16.3 & - & 0.8 & 71 \\
\hline Mold oil ${ }^{c}$ & 33.1 & - & 3.7 & 46.6 & 10.1 & 5.6 & - & 700 \\
\hline \multicolumn{9}{|l|}{ Exp. 3} \\
\hline Palm oil & 42.8 & - & 4.2 & 40.3 & 10.5 & - & 0.4 & 21 \\
\hline Ethyl- $\gamma$-linolenate & - & - & - & 1.0 & 4.2 & 94.2 & - & - \\
\hline Ethyl-linoleate & - & - & - & 3.3 & 95.0 & - & 0.8 & - \\
\hline
\end{tabular}

a Expressed as $\mathrm{mg} / 100 \mathrm{~g}$.

$b, c$ These oils were from different batches.

${ }^{d}$ Contained $2.4 \%$ safflower oil to adjust the content of polyunsaturated fatty acids to be equivalent to that of the mold oil. 
Table II. Compositions of Diets

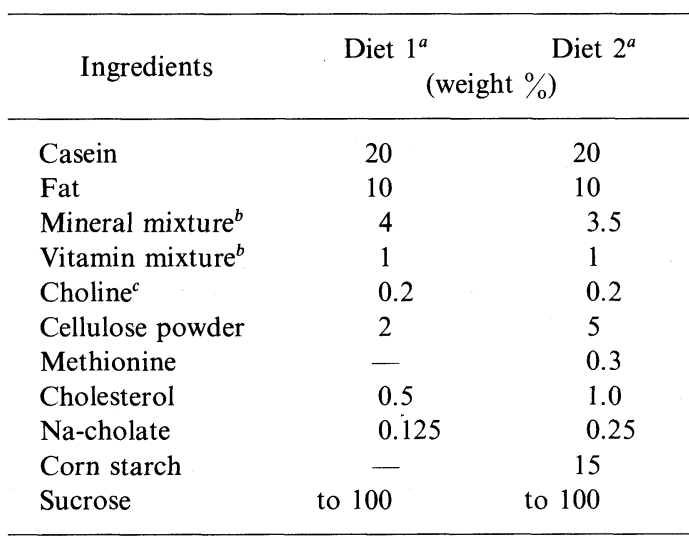

a Diet 1 was used in Exp. 1 and Diet 2 in Exps. 2 and 3.

${ }^{b}$ Harper $^{14)}$ and AIN-76 $6^{15)}$ mixtures in Diet 1 and Diet 2 , respectively.

c Choline chloride and choline bitartrate in Diet 1 and Diet 2 , respectively.

portion $(2.4 \%)$ of palm olein was replaced by safflower oil to make the total polyunsaturated fatty acid (C18:2 and $\mathrm{C} 18: 3)$ cotent equivalent to that of the mold oil. In addition, $\beta$-sitosterol $(93 \% \beta$-sitosterol and $7 \%$ campesterol, ICN Pharmaceuticals, Inc., Cleveland $\mathrm{OH}$ ) was added to safflower oil and palm olein to make the total phytosterol contents equivalent among the three dietary fats. A small volume of blood was collected weekly from the tail vein at around $1400 \mathrm{hr}$ after depriving the rats of diets for $5 \mathrm{hr}$ for enzymatic measurement of serum cholesterol (Cholesterol C-Test, Wako Pure Chemicals Co., Osaka). The blood samples were obtained from the abdominal aorta after overnight fasting 2 days after the final serial blood sampling.

Exp. 3. Rats weighing an average of 135 (Exp. 3-1) to $140 \mathrm{~g}$ (Exp. 3-2) were fed on the experimental diet (Diet 2 in Table II) for 11 days. Two sets of experiments (Exps. 3-1 and 3-2) were done using ethyl-GLA and ethyl-LA as substitutes for palm oil. Serum cholesterol levels were measured before experiments and the animals were divided into groups with the same average cholesterol levels. The initial fasting levels of serum cholesterol were $66.4 \pm 1.7$ and $64.0 \pm 1.8 \mathrm{mg} / \mathrm{dl}$ for Exps. 3-1 and $3-2$, respectively. Blood was collected from the abdominal aorta after overnight fasting.

Lipid analyses. Plasma and liver lipids were analyzed for cholesterol, triglyceride, and phospholipid as described elsewhere. $^{16)}$ The fatty acid composition ${ }^{17)}$ and phytosterol content ${ }^{18)}$ were analyzed by gas-liquid chromatography.

Eicosanoid measurement. The production by the abdominal aorta of prostacyclin (measured as 6-keto-PGF $\mathrm{F}_{1 \alpha}$ ) and concentrations of plasma $\mathrm{TXB}_{2}, \mathrm{PGE}_{1}$, and $\mathrm{PGE}_{2}$ were measured using commercial radioimmunoassay kits (New England Nuclear NEK-007 and 008, Boston MA for $\mathrm{TXB}_{2}$ and 6-keto-PGF ${ }_{1 \alpha}$, and Seragen RIA kits SG 6013 and 6001 , Boston MA for $\mathrm{PGE}_{1}$ and $\mathrm{PGE}_{2}$, respectively) as reported previously. ${ }^{19)}$

$\Delta^{6}$-Desaturase assay. The $\Delta^{6}$-desaturase activity in liver microsomes was measured using $\left[1-{ }^{14} \mathrm{C}\right]$ linoleic acid (Amersham International plc, Buckinghamshire, England) as a substrate by the method of Svensson. ${ }^{20)}$

Statistical analyses. Data were analyzed either by Student's $t$-test (Exp. 1) or by one-way analysis of variance followed by inspection of all differences between pairs of means (Exps. 2 and 3 ) at the level of $p<0.05 .^{21)}$

\section{RESULTS}

\section{Comparison between mold oil and safflower oil} (Exp. 1)

The crude mold oil did not have any untoward effect on the growth (weight gain for 24 days, $193 \pm 6$ and $187 \pm 8 \mathrm{~g}$ for the safflower oil and mold oil groups, respectively) or food consumption $(18.9 \pm 0.4$ and $19.7 \pm$ $0.7 \mathrm{~g})$. The liver weight was also comparable $(6.36 \pm 0.20$ and $6.69 \pm 0.20 \mathrm{~g} / 100 \mathrm{~g}$ body weight).

As shown in Table III, the concentration of plasma cholesterol was comparable between rats fed the mold oil and safflower oil, while that of triglyceride was significantly lower in the former. The liver cholesterol level was also comparable between the two groups, but the triglyceride level was significantly lower in rats fed safflower oil.

The aorta from rats fed the mold oil, as compared with those from rats fed safflower oil, produced significantly more $\mathrm{PGI}_{2}$ (Fig. 1). In contrast, plasma concentrations of $\mathrm{TXB}_{2}$ and $\mathrm{PGE}_{1}$ were significantly lower in the mold oil group. The activity of $\Delta^{6}$-desaturase of the liver microsomes was significantly higher in rats fed the mold oil than in those fed safflower oil $(44.9 \pm 3.7$ and $75.2 \pm 9.2 \mathrm{pmol} / \mathrm{min} / \mathrm{mg}$ protein, $p<0.05)$.

As Table IV shows, the percentage of LA in liver phosphatidylcholine was much lower while that of AA was rather higher in rats fed the mold oil than in those fed safflower oil. 
Table III. Effects of Dietary Fats on Concentrations of Plasma and LIVER LIPIDS (Exp. 1)

\begin{tabular}{|c|c|c|c|c|c|c|}
\hline \multirow{2}{*}{ Dietary fats } & \multicolumn{3}{|c|}{ Plasma lipids (mg/dl) } & \multicolumn{3}{|c|}{ Liver lipids (mg/g) } \\
\hline & $\mathrm{CHOL}$ & TG & PL & $\mathrm{CHOL}$ & TG & PL \\
\hline Safflower oil & $126 \pm 8$ & $189 \pm 22^{a}$ & $144 \pm 6^{a}$ & $51.5 \pm 4.3$ & $49.3 \pm 4.4^{a}$ & $27.4 \pm 0.9$ \\
\hline Mold oil & $138 \pm 5$ & $127 \pm 15$ & $179 \pm 6$ & $46.8 \pm 2.8$ & $64.5 \pm 5.4$ & $29.4 \pm 1.0$ \\
\hline
\end{tabular}

Values are means \pm S.E. of 8 rats per group. CHOL, cholesterol; TG, triglyceride; PL, phospholipid.

a Significantly different from the mold oil group at $p<0.05$.

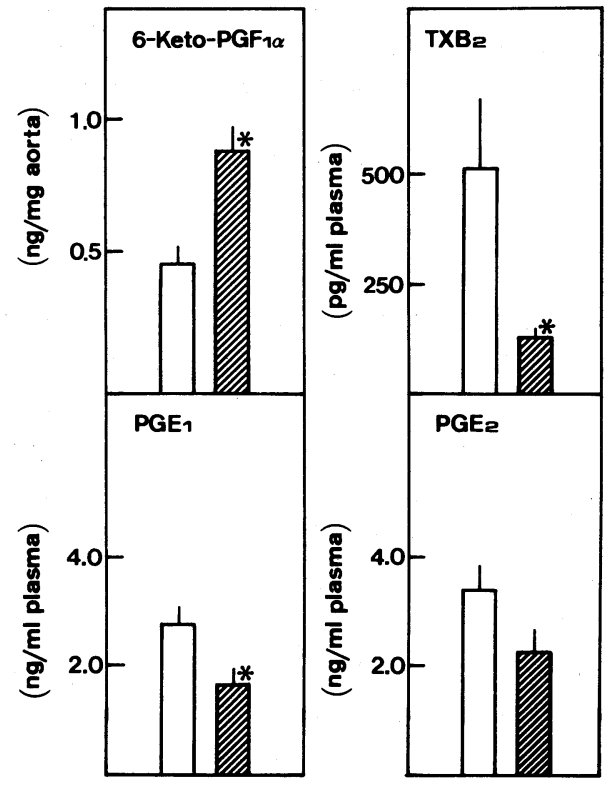

FIG. 1. Effects of Dietary Fats on the Aortic Production and Plasma Concentrations of Eicosanoids (Exp. 1).

Values are means \pm S.E. (vertical extension) of 8 to 9 rats per group. $\square$, safflower oil; प्wla, mold oil.

* Significantly different from the safflower oil group at $p<0.05$.

Consequently, the ratio of AA/LA was significantly high in the mold oil group $(p<0.05)$.

Comparison among mold oil, safflower oil, and palm olein (Exp. 2)

During the 44 days of the feeding period, body weight gain tended to be high in the mold oil group $(275 \pm 11,307 \pm 7$, and $314 \pm$ $20 \mathrm{~g}$ for the safflower oil, palm olein, and mold oil groups, respectively). Food intake was significantly lower in rats fed safflower oil $(20.0 . \pm 0.4 \mathrm{~g} /$ day $)$ than in those fed palm

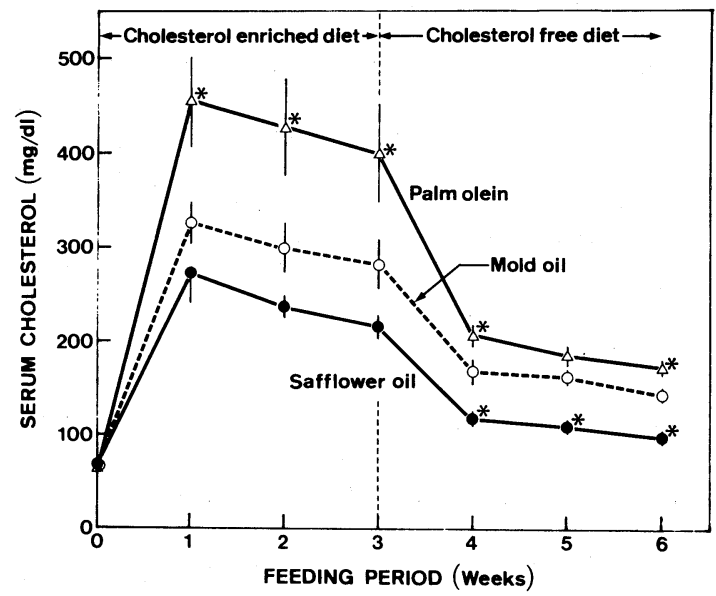

FIG. 2. Effects of Dietary Fats on the Changes in Concentrations of Serum Cholesterol (Exp. 2).

Values are means \pm S.E. of 8 rats per group.

* Significantly different from the values without asterisk at $p<0.05$.

olein $(22.8 \pm 0.4 \mathrm{~g} /$ day, $p<0.05)$ but not the mold oil $(21.8 \pm 1.0 \mathrm{~g} /$ day $)$. The liver weight was comparable $(4.10 \pm 0.08,4.33 \pm 0.06$, and $4.19 \pm 0.15 \mathrm{~g} / 100 \mathrm{~g}$ body weight for safflower oil, palm olein, and the mold oil, respectively).

The changes of the serum cholesterol level clearly showed that, regardless of an equivalent supply of total polyunsaturated fatty acids, the mold oil was significantly more hypocholesterolemic than palm olein with diets rich in cholesterol (Fig. 2). In contrast, the difference in the serum cholesterol level between the mold oil and safflower oil groups was statistically insignificant, although it tended to be slightly but consistently higher in the former. When switched to cholesterolfree diets, serum cholesterol decreased sharply 
Table IV. Effects of Dietary Fats on Fatty Acid Compositions of Liver Phosphatidylcholine (Exps. 1 and 2 )

\begin{tabular}{|c|c|c|c|c|c|c|c|c|c|c|}
\hline \multirow{2}{*}{ Dietary fats } & \multicolumn{10}{|c|}{ Fatty acids (weight $\%$ ) } \\
\hline & $16: 0$ & $16: 1$ & $18: 0$ & $18: 1$ & $18: 2$ & $18: 3(\mathrm{n} 6)$ & $18: 3(\mathrm{n} 3)$ & $20: 3$ & $20: 4$ & $22: 6$ \\
\hline \multicolumn{11}{|l|}{ Exp.1 } \\
\hline Safflower oil & $20.7 \pm 0.9$ & $1.8 \pm 0.4$ & $13.1 \pm 0.8^{a}$ & $10.4 \pm 0.6^{a}$ & $22.6 \pm 0.7^{a}$ & $0.2 \pm 0.1$ & $0.5 \pm 0.1$ & $2.9 \pm 0.3^{a}$ & $21.3 \pm 0.9^{a}$ & $1.4 \pm 0.2$ \\
\hline Mold oil & $21.6 \pm 0.4$ & $2.7 \pm 0.4$ & $15.4 \pm 0.2^{b}$ & $17.8 \pm 0.5^{b}$ & $5.5 \pm 0.1^{b}$ & $0.5 \pm 0.1$ & $0.4 \pm 0.0$ & $7.5 \pm 0.6^{b}$ & $25.3 \pm 0.6^{b}$ & $0.8 \pm 0.2$ \\
\hline \multicolumn{11}{|l|}{ Exp. 2} \\
\hline Safflower oil & $20.9 \pm 0.5$ & $1.0 \pm 0.1^{a}$ & $16.8 \pm 0.9$ & $6.3 \pm 0.4^{a}$ & $14.4 \pm 0.5^{a}$ & $0.1 \pm 0.0^{a}$ & $0.4 \pm 0.0$ & $1.3 \pm 0.1$ & $32.8 \pm 0.6$ & $1.4 \pm 0.1^{a}$ \\
\hline Palm olein & $22.2 \pm 0.4$ & $2.1 \pm 0.1^{b}$ & $15.6 \pm 0.8$ & $14.0 \pm 0.4^{b}$ & $7.1 \pm 0.6^{b}$ & $0.2 \pm 0.0^{a}$ & $0.6 \pm 0.1$ & $1.5 \pm 0.3$ & $29.8 \pm 0.8$ & $2.2 \pm 0.1^{b}$ \\
\hline Mold oil & $22.9 \pm 0.8$ & $2.3 \pm 0.3^{b}$ & $14.3 \pm 0.7$ & $14.8 \pm 0.3^{b}$ & $4.7 \pm 0.2^{c}$ & $0.3 \pm 0.0^{b}$ & $0.5 \pm 0.1$ & $2.0 \pm 0.2$ & $31.3 \pm 1.5$ & $1.1 \pm 0.1^{a}$ \\
\hline
\end{tabular}

Values are means \pm S.E. of 6 to 8 rats per group.

a.b,c In each experiment values not sharing common superscript letters are different significantly at $p<0.05$. 
in all groups, while the rate of decrease was to some extent greater in rats fed palm olein. However, the difference between the mold oil and palm olein still existed except for one time. Concentrations of serum cholesterol during cholesterol-free diets were slightly but significantly lower in the safflower oil group than in the mold oil group throughout. At the end ( 2 days after final serial blood sampling), the fasting plasma levels of triglyceride were, in addition to cholesterol, significantly lower $(p<0.05)$ in rats fed safflower oil than in those fed either the mold oil or palm olein $(45.3 \pm 2.2,90.7 \pm 15.8$, and $94.9 \pm 14.9 \mathrm{mg} / \mathrm{dl}$ for safflower oil, mold oil, and palm olein, respectively). However, concentrations of plasma phospholipid and liver lipids were all comparable among the different groups (values not shown), although considerable amounts of cholesterol still remained in the liver (average 38.1 to $47.6 \mathrm{mg} / \mathrm{g}$ ).

As Table $\mathrm{V}$ shows, the production of $\mathrm{PGI}_{2}$ (measured as 6-keto-PGF ${ }_{1 \alpha}$ ) by the aorta and the concentration of plasma $\mathrm{TXB}_{2}$ and $\mathrm{PGE}_{1}$

Table V. EfFects of Dietary Fats on the Aortic Production and Plasma Concentrations of EicosanoIDS (Exp. 2)

\begin{tabular}{lccc}
\hline Dietary fats & $\begin{array}{l}\text { 6-Keto-PGF } \\
(\mathrm{pg} / \mathrm{mg} \text { aorta })\end{array}$ & $\begin{array}{c}\mathrm{TXB}_{2} \\
(\mathrm{pg} / \mathrm{ml} \text { plasma })\end{array}$ \\
\hline Safflower oil & $559 \pm 91$ & $481 \pm 254$ & $994 \pm 119$ \\
Palm olein & $524 \pm 70$ & $515 \pm 140$ & $886 \pm 202$ \\
Mold oil & $685 \pm 61$ & $307 \pm 118$ & $1032 \pm 188$ \\
\hline
\end{tabular}

Values are means \pm S.E. of 3 to 8 rats per group.

Table VI. EfFects of Dietary Fats on Fecal ExCretion of Neutral and ACIDiC STEROIDS (Exp. 2)

\begin{tabular}{lcc}
\hline Dietary fats & $\begin{array}{c}\text { Neutral steroids } \\
(\mathrm{mg} / \text { day })\end{array}$ & $\begin{array}{c}\text { Acidic steroids } \\
(\mathrm{mg} / \mathrm{day})\end{array}$ \\
\hline Safflower oil & $101 \pm 4$ & $31.3 \pm 1.3$ \\
Palm olein & $104 \pm 5$ & $29.4 \pm 3.3$ \\
Mold oil & $108 \pm 6$ & $26.6 \pm 2.1$ \\
\hline
\end{tabular}

Values are means \pm S.E. of 6 rats per group. Feces collected after one week of feeding experimental diets were analyzed.

${ }^{a}$ Includes cholesterol and coprostanol. were indistinguishable among different groups due to large variations in each value.

The fatty acid composition of liver phosphatidylcholine of the palm olein group resembled that of the mold oil group except for a significantly lower value for LA in the latter, reflecting the profile of dietary fat (Table IV). The response of the safflower oil and mold oil groups was comparable with that observed in the preceding experiment with cholesterol-enriched diets (Exp. 1) and the ratio $\mathrm{AA} / \mathrm{LA}$ was much higher in the latter. The profiles of plasma phosphatidylcholine resembled those of the liver counterpart (values not shown). The fatty acid compositions of the adipose tissue lipids reflected those of dietary fats; percentages of LA were 8.7 and $11.3 \%$, and those of GLA were 1.8 and $0.1 \%$ for the mold oil and palm olein groups, respectively. The corresponding values for the safflower oil group were 56.6 and $0.1 \%$, respectively.

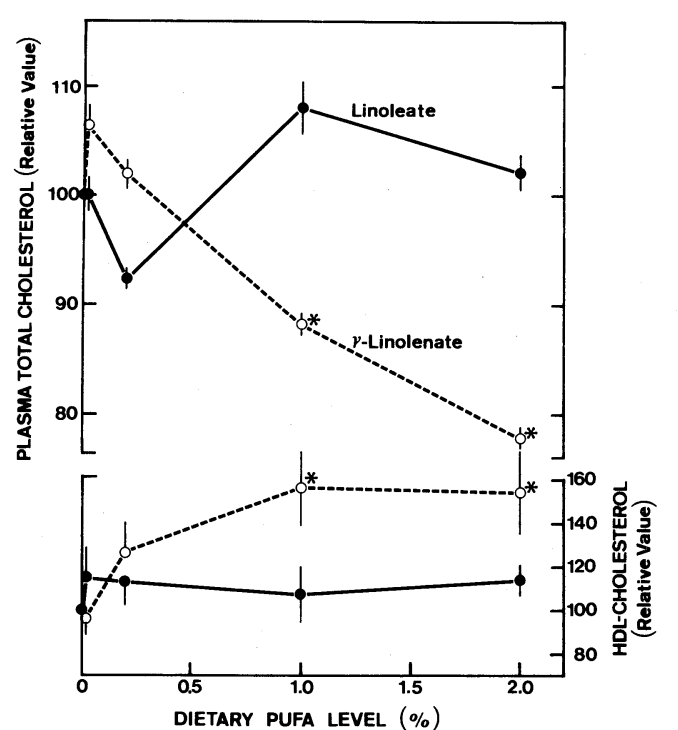

FIG. 3. Effects of Dietary Fats on Concentrations of Serum Total- and HDL-Cholesterol (Exp. 3).

Values are means \pm S.E. of 6 rats per group. Total cholesterol levels in rats fed palm oil alone (the control groups) were $140 \pm 4$ and $143 \pm 13 \mathrm{mg} / \mathrm{dl}$ for experiments with GLA and LA, respectively. The corresponding values for HDL-cholesterol were $18.1 \pm 0.8$ and $.21 .2 \pm 2.1 \mathrm{mg} / \mathrm{dl}$.

* Significantly different from the ethyl-linoleate group at $p<0.05$. 
Table VI shows that fecal excretion of neutral and acidic steroids one week after feeding experimental diets was comparable among all of the groups. We have shown that the effect of dietary fat on fecal steroid excretion was greatest at this stage of the feeding period.9) The daily excretion of neutral steroids remained unchanged until the third week, while that of acidic steroids after three weeks was significantly higher on safflower oil $(38.8 \pm 1.3 \mathrm{mg} / \mathrm{day})$ than on palm olein $(32.1 \pm 1.5 \mathrm{mg} / \mathrm{day})$ and the mold oil $(30.8 \pm$ $1.2 \mathrm{mg} /$ day).

\section{Comparison between $\gamma$-linolenate and linoleate (Exp. 3)}

The effects of partial replacement of palm oil with either ethyl-GLA or ethyl-LA were studied separately. In both trials the partial substitution of polyunsaturated fatty acids for palm oil did not have any effects on food intake, weight gain, or liver weight (values not shown). After 11 days of the experimental diets, plasma cholesterol levels of the two palm oil groups (the control groups) were $140 \pm 4$ and $143 \pm 13 \mathrm{mg} / \mathrm{dl}$ for experiments with GLA and LA, respectively. Since the experimental conditions were all the same, it seemed reasonable to compare these two independent

Table VII. Effects of Dietary Fats on the Aortic Production and Plasma Concentrations of EICOSANOIDS (Exp. 3)

\begin{tabular}{cccc}
\hline Dietary fats & $\begin{array}{c}\text { 6-Keto- } \\
\text { PGF }_{1 \alpha} \\
\text { (pg/mg aorta) }\end{array}$ & $\begin{array}{c}\mathrm{TXB}_{2} \\
(\mathrm{pg} / \mathrm{ml} \text { plasma })\end{array}$ \\
\hline Exp. 3-1 & & & \\
10\% Palm oil & $831 \pm 26^{a}$ & $222 \pm 115$ & $504 \pm 77$ \\
$2 \%$ GLA-8\% palm & $1696 \pm 221$ & $168 \pm 82$ & $777 \pm 160$ \\
oil & & & \\
Exp. 3-2 & & & \\
$10 \%$ Palm oil & $199 \pm 33$ & $282 \pm 91$ & $697 \pm 103$ \\
$2 \%$ LA-8 $^{b}$ palm & $244 \pm 32$ & $340 \pm 117$ & $795 \pm 79$ \\
oil $^{b}$ & & & \\
\hline
\end{tabular}

Values are means \pm S.E. of 3 to 6 rats per group.

a Significantly different from the GLA-palm oil group at $p<0.05$.

${ }^{b}$ GLA, ethyl- $\gamma$-linolenate; LA, ethyl-linoleate. experiments simultaneously. Figure 3 shows that the effect of the replacement of palm oil with ethyl-GLA on the serum cholesterol level was dose-dependent, while ehtyl-LA did not have any measurable effect on this parameter. In contrast, the HDL-cholesterol level $(18.1 \pm 0.8$ and $21.2 \pm 2.1 \mathrm{mg} / \mathrm{dl}$ for the control groups in experiments with GLA and LA, respectively) increased in response to the dietary GLA and reached a plateau at $10 \%$ substitution, whereas the linoleate again had no demonstrable effect.

The concentration of liver cholesterol but not triglyceride and phospholipid decreased upon the inclusion of ethyl-GLA at the level above $1 \%$ and the difference was significant $(p<0.05) \quad(49.8 \pm 1.5, \quad 50.9 \pm 1.9, \quad 49.3 \pm 2.7$, $37.0 \pm 1.0$, and $37.4 \pm 2.6 \mathrm{mg} / \mathrm{g}$ for $0,0.02,0.2$, 1 , and $2 \%$ GLA, respectively).

As Table VII shows, ethyl-GLA influenced the pattern of eicosanoids. The aortic production of $\mathrm{PGI}_{2}$, measured as 6-keto-PGF $1 \alpha$, increased significantly and the concentration of plasma $\mathrm{TXB}_{2}$ tended to decrease. There was an increasing trend toward the plasma level of $\mathrm{PGE}_{1}$ in rats fed ethyl-GLA. In contrast, ethyl-LA did not exert any detectable effects on eicosanoids.

\section{DISCUSSION}

Our studies confirmed a potent hypocholesterolemic efficacy of the mold oil. Thus, the mold oil which contains $6 \%$ GLA and $10 \%$ LA was found to be as effective as safflower oil containing $75 \%$ LA. Alternatively, the mold oil, in which the ratio of polyunsaturated/ saturated (excludes stearic acid) fatty acids $(\mathrm{P} / \mathrm{S})$ is approximately one-twentieth that of safflower oil, exerted a comparable cholesterol-lowering activity. In addition, when compared with palm olein which was arranged to have a fatty acid composition equivalent to that of the mold oil except for the construction of polyunsaturated fatty acids, the mold oil was clearly more hypocholesterolemic. Experiments with ethyl-GLA and LA gave the same line of evidence. These observations in- 
dicate that GLA in the mold oil is primarily responsible for its hypocholesterolemic effect. ${ }^{22)}$ Our study also suggests the possible use of Mortierella oil as a substitute for evening primrose oil, as the productivity of this oil is quite promising. ${ }^{12)}$ In addition, since the mold oil, as compared with evening primrose oil, contains less LA relative to GLA, the inexpedient effect of $\mathrm{LA}^{3,4)}$ could be more readily evaded by the use of the mold oil. The mold oil should also be a better source than evening primrose oil for isolating GLA. In fact, the GLA-rich mold oil can be easily obtained by a simple one-step wintering process $(11 \%$ GLA and $13 \%$ LA). However, the effect of the mold oil on the serum cholesterol level was not necessarily the same as that of safflower oil as the concentration of plasma and liver cholesterol remained at a high level in rats fed this oil in relation to rats fed safflower oil when the cholesterol-enriched diet was switched to the cholesterol-free diet.

The mechanism underlying the eminent hypocholesterolemic action of GLA remains unknown. Although changes in cholesterol dynamics should be measured before making any conclusions on the mechanism of action of GLA, the cholesterol-lowering effect of evening primrose oil in preference to safflower oil could not at least be ascribed to the enhanced fecal excretion of steroids. ${ }^{10)}$ Also, in this study the excretion of fecal steroids was not influenced by dietary fats (Table VI). We examined here the effects of different fat types on the production of eicosanoids since some prostaglandins have detectable hypocholesterolemic effects. ${ }^{8,23,24)}$ A significant increase in the aortic production of $\mathrm{PGI}_{2}$ measured as 6-keto- $\mathrm{PGF}_{\mathrm{i}_{\alpha}}$ and a significant reduction of the concentration of plasma $\mathrm{TXB}_{2}$ in the mold oil group in relation to the safflower oil group (Fig. 1) predict an antithrombotic and hence antiatherogenic nature of the mold oil. ${ }^{25)}$ This effect could be attributable to the presence of GLA since ethyl-GLA provoked a similar type of response. However, this preferable effect was unclear when rates were fed cholesterolfree diets following cholesterol-enriched diets.
Thus, the mold oil seems to exert its effect on the production of eicosanoids when the supply of the substrate is restricted due to a reduced desaturation of polyunsaturated fatty acids by dietary cholesterol. ${ }^{5,26,27)}$ Of course, the plasma level of one prostaglandin may not simply reflect the productivity alone. ${ }^{25)}$

Although the data for concentrations of various eicosanoids are indeed difficult to evaluate, the results on the fatty acid compositions (Table IV) clearly indicate an efficient desaturation of GLA to AA as compared with LA, and hence possibly suggest different availabilities of substrates for the formation of eicosanoids. Contrary to our expectation, however, the effect of the mold oil on the concentration of plasma $\mathrm{PGE}_{1}$ was rather variable. ${ }^{22)}$ The $\Delta^{6}$-desaturase is the ratelimiting enzyme in the desaturation of LA to GLA and its activity is influenced by a variety of factors including dietary cholesterol and the type of dietary fats. ${ }^{26,27)}$ The $\Delta^{6}$-desaturase specific activity in liver microsomes was significantly higher in rats fed the mold oil than in those fed safflower oil. The rise of the enzyme activity could not be seen when rats were fed evening primrose oil. ${ }^{19)}$ Thus, although the content of GLA is comparable in the mold oil and evening primrose oil, the fatty acid composition of the former seems to be preferable for desaturation and hence the production of specific eicosanoids. However, the contribution of palmitic acid, an abundant fatty acid in the mold oil, toward the increased aortic production of $\mathrm{PGI}_{2}$ is not ruled out at present, since saturated fatty acid intake, in animal models, has been associated with increased arterial $\mathrm{PGI}_{2}$ release. ${ }^{28,29)}$

In conclusion, GLA-containing oil produced by the mold Mortierella sp. was found to have a potent hypocholesterolemic activity, regardless of the fairly low $\mathrm{P} / \mathrm{S}$ ratio. This peculiar fatty acid composition seemed to be favorable for desaturation of polyunsaturated fatty acids including LA and hence give rise to a specific profile of eicosanoids. The specific effect of the mold oil on the metabolism of cholesterol was attributed almost exclusively 
to GLA, and the effects became clearer when rats were fed cholesterol-enriched diets.

Acknowledgment. Dr. O. Suzuki, National Chemical Laboratory for Industry, Japan kindly provided Mortierella ramanniana var. angulispora IFO 8187 together with the basic culturing methods.

\section{REFERENCES}

1) A. Keys, J. T. Anderson and F. Grande, Lancet, ii, 959 (1957).

2) D. M. Hegsted, R. B. McGandy, M. L. Meyers and F. J. Stare, Am. J. Clin. Nutr., 17, 281 (1965).

3) Committee on Diet, Nutrition, and Cancer, Assembly of Life Science, National Research Council, "Diet, Nutrition, and Cancer," National Academy Press, Washington, D. C., 1982, pp. 5$1 \sim 5-33$.

4) A. D. Smith, "The Role of Fats in Human Nutrition," ed. by F. B. Padley and J. Podmore, Ellis Horwood, Chichester, 1985, p. 157.

5) K. Katayasu and I. Yoshikawa, Lipids, 6, 47 (1971).

6) D. F. Horrobin and M. S. Manku, Lipids, 18, 558 (1983).

7) J. P. Poisson and J. P. Blond, Arch. Int. Physiol. Biochem., 91, 361 (1983).

8) Y. S. Huang, M. S. Manku and D. F. Horrobin, Lipids, 19, 664 (1984).

9) A. Szczeklik, R. J. Gryglewski, K. Sladek, E. Kostka-Trabka and A. Zmuda, Thromb. Haemostas. (Stuttgart), 51, 186 (1984).

10) M. Sugano, T. Ide, T. Ishida and K. Yoshida, Ann. Nutr. Metab., 30, (1986) in press.

11) B. J. Hudson, J. Am. Oil Chem. Soc., 61, 540 (1984).

12) O. Suzuki, T. Yokochi and T. Yamashina,
Yukagaku, 30, 863 (1981).

13) W. W. Christie, "Lipid Analysis," 2nd Ed., Pergamon Press, Oxford, 1982, pp. 90 91.

14) A. E. Harper, J. Nutr., 68, 405 (1959).

15) American Institute of Nutrition Ad Hoc Committee on Standards for Nutritional Studies, J. Nutr., 107, 1340 (1977).

16) Y. Nagata, K. Imaizumi and M. Sugano, Brit. J. Nutr., 44, 113 (1981).

17) M. Sugano, K. Ryu and T. Ide, J. Lipid Res., 25, 474 (1985).

18) M. Sugano, F. Kamo, I. Ikeda and H. Morioka, Atheroscl., 24, 301 (1976).

19) M. Sugano, T. Ishida and T. Ide, Agric. Biol. Chem., 50, 2335 (1986).

20) L. Svensson, Lipids, 18, 171 (1983).

21) G. W. Snedecor and W. G. Cochran, "Statistical Methods," 6th Ed., Iowa State University Press, Ames, IA, 1976, pp. 258, 298.

22) A. G. Hassan, "The Role of Fats in Human Nutrition," ed. by F. B. Padley and J. Podmore, Ellis Horwood, Chichester, 1985, p. 84.

23) A. L. Willis, Lancet, ii, 697 (1984).

24) W. Krone, P. Kaczmarck, D. Muller-Wieland and H. Greten, Arterioscl., 4, 543a (1984).

25) M. Toda and T. Kuzuya, Seikagaku, 57, 1361 (1985).

26) R. R. Brenner, Prog. Lipid Res., 20, 41 (1981).

27) R. Jeffcoat and A. T. James, "Fatty Acid Metabolism and Its Regulation," ed. by S. Numa, Elsevier Science Publishers, B. V., Amsterdam, 1984, p. 85 .

28) E. A. M. de Deckere, D. H. Nugteren and F. ten Hoor, Prostaglandins, 17, 947 (1979).

29) C. Galli, E. Agradi, A. Petroni and E. Tremoli, Lipids, 16, 165 (1981). 